\title{
O acesso à cidadania no Estado da Bahia: reconstruindo os caminhos pelas
}

\section{tecnologias de plataformas públicas no Brasil}

Access to citizenship in the State of Bahia: rebuilding the paths through public platform

\author{
technologies in Brazil
}

Acceso a la ciudadanía en el Estado de Bahía: reconstruyendo los caminos a través de tecnologías

de plataforma pública en Brasil

\section{Resumo}

Este artigo procurou analisar a cidadania no Brasil, em seus aspectos de acesso e desfrute, tendo o estado da Bahia como referência, pelo trabalho de Prado (2017). Autores têm afirmado que a cidadania tem sido marcada pela seletividade, nesses fundamentos. Assim, conceitualmente recorreu-se a cidadania social em Marshall (1967), com os princípios de igualdade, liberdade e autonomia de participação e gozo, por parte dos indivíduos. Nesse sentido, acesso e desfrute são questões elementares. Assim, o problema é descortinar se além das plataformas públicas e da plataforma postal, a plataforma de serviços extrajudiciais pode ser também um instrumento que o Estado brasileiro dispõe, para ampliar a oferta de serviços de acesso à cidadania, com foco mais específico para o documento certificador "Carteira de identidade (CI)". O objetivo é analisar a plataforma de serviços extrajudiciais, visando compreender os recursos disponíveis, para facilitar o acesso à cidadania, para o serviço de Carteira de Identidade (CI). Justifica-se a pesquisa por ter encontrado em Prado (2017), estudo que aponta para as fragilidades na oferta dos serviços (documentos certificadores) e as opções de expansão dos serviços para a população do estado da Bahia. A pesquisa possui natureza descritiva/exploratória operacionalizada por meio de análise comparativa. Como resultado constatou-se a existência de uma ampla plataforma de atendimento a cidadania (a de serviços extrajudiciais), com fé pública, já implantada pelo Brasil a mais tempo, mas no estado da Bahia, somente a partir de 2017, com plena capacidade de proporcionar o acesso à diversos serviços para a cidadania, porém, mais uma plataforma pouco explorada pelo Estado.

Palavras-chave: Cidadania; Plataformas públicas; Serviços extrajudiciais.

\begin{abstract}
This article sought to analyze citizenship in Brazil, in its aspects of access and enjoyment, having the state of Bahia as a reference, through the work of Prado (2017). Authors have stated that citizenship has been marked by selectivity, on these grounds. Thus, conceptually, social citizenship was used in Marshall (1967), with the principles of equality, freedom and autonomy of participation and enjoyment on the part of individuals. In this sense, access and enjoyment are elementary issues. Thus, the problem is to unveil whether, in addition to public platforms and the postal platform, the extrajudicial services platform can also be an instrument that the Brazilian State has to expand the offer of access to citizenship services, with a more specific focus on the document "Identity Card (CI)" certifier. The objective is to analyze the platform of extrajudicial services, aiming to understand the resources available, to facilitate access to citizenship, for the Identity Card (CI) service. The research is justified because it found in Prado (2017), a study that points to the weaknesses in the provision of services (certifying documents) and the options for expanding services for the population of the state of Bahia. The research has a descriptive/exploratory nature operationalized through comparative analysis. As a result, it was found that there is a broad platform for citizen service (extrajudicial services), with public faith, already implemented by Brazil for a longer time, but in the state of Bahia, only from 2017
\end{abstract}


onwards, with full capacity to provide access to various services for citizenship, however, another platform little explored by the State.

Keywords: Citizenship; Public platforms; Extrajudicial services.

\section{Resumen}

Este artículo buscó analizar la ciudadanía en Brasil, en sus aspectos de acceso y disfrute, teniendo como referência al estado de Bahía, a través del trabajo de Prado (2017). Los autores han afirmado que la ciudadanía há estado marcada por la selectividad, por estos motivos. Así, conceptualmente, se utilizó la ciudadanía social en Marshall (1967), con los principios de igualdad, libertad y autonomía de participación y disfrute por parte de los individuos. En este sentido, el acceso y el disfrute son cuestiones elementales. Así, el problema es develar si, además de las plataformas públicas y la plataforma postal, la plataforma de servicios extrajudiciales también puede ser un instrumento que tiene el Estado brasileño para ampliar la oferta de acceso a los servicios de ciudadanía, con un enfoque más específico en la documento certificador "Cédula de Identidad (CI)". El objetivo es analizar la plataforma de servicios extrajudiciales, con el objetivo de conocer los recursos disponibles, para facilitar el acceso a la ciudadanía, para el servicio de Cédula de Identidad (CI). La investigación se justifica porque encontró en Prado (2017), un estudio que apunta a las debilidades en la prestación de servicios (documentos acreditativos) y las opciones de ampliación de servicios para la población del estado de Bahía. La investigación tiene un carácter descriptivo / exploratorio operacionalizado a través del análisis comparativo. Como resultado, se encontró que existe una amplia plataforma de atención ciudadana (servicios extrajudiciales), con fe pública, ya implementada por Brasil desde hace más tiempo, pero en el estado de Bahía, solo a partir de 2017, con plena capacidad para Brindar acceso a diversos servicios para la ciudadanía, sin embargo, otra plataforma poco explorada por el Estado.

Palabras clave: Ciudadanía; Plataformas públicas; Servicios extrajudiciales.

\section{Introdução}

Este trabalho tem como tema o acesso à cidadania no Brasil, tendo como base o estado da Bahia, destacado pelo trabalho de Prado (2017), o qual promoveu uma discussão inicial sobre alguns dos fundamentos para o exercício da cidadania, principalmente pela perspectiva do acesso e do desfrute. Este autor, sem desconsiderar outras perspectivas, fez uma opção por adotar como ponto de partida o conceito de cidadania social proposto por Marshall (1967, p. 56), como sendo "uma espécie de igualdade humana básica, associada com o conceito de participação integral na sociedade”.

Para Prado (2017), a ideia do acesso à cidadania no Brasil passa obrigatoriamente pela concepção institucional de fichas simbólicas (conceito cunhado por Giddens, 1991), sendo elementos trazidos pela modernidade, as quais são convertidas no construto estabelecido por esse autor, como documentos certificadores para acesso à cidadania. Esses documentos, quando fornecidos pelo Estado, seriam os responsáveis por legitimarem um indivíduo como cidadão, dando a ele o direito de acesso aos espaços ou arenas da cidadania, que na concepção da cidadania social de Marshall (1967), essas arenas se constituem em adquirir direitos civis (ou individuais), direitos políticos e direitos sociais (ou econômicos).

Prado (2017), utilizando autores como Souza (2006) e Holston (2013), procurou demonstrar que, ao seguir a lógica de análise do primeiro autor, constata-se a existência de uma seletividade no acesso à cidadania no Brasil, resultando em categorias como cidadãos e subcidadãos. Já sob a análise do segundo autor, no Brasil constata-se a existência de uma cidadania entrincheirada (com privilégios), e uma cidadania insurgente, que só adquire acesso e desfrute exatamente por sua insurgência. Na realidade, Prado (2017) procura enfatizar com essas leituras a incapacidade do Estado brasileiro em oferecer pleno acesso à cidadania, ou mais especificamente como objeto de seu trabalho, aos documentos certificadores que, por consequência, irão recair, em não tendo acesso, sobre o próprio desfrute da cidadania.

Ao analisar o estado da Bahia, este autor utilizou dados extraídos do censo do IBGE (2010), pelo qual verificou um espaço territorial amplo, com $564.831 \mathrm{~km}^{2}$ de extensão, representando $6,6 \%$ de todo o território brasileiro, com condições pouco favoráveis ao exercício da cidadania plena, apontadas em vários estudos e indicadores oficiais, bem como demonstrado historicamente na literatura, que pode ser ancorada, por exemplo, no trabalho de Spínola (2009, p. 444).

Os fatos de todos os municípios baianos dependerem do apoio federal e estadual para sobreviver, pois a participação dos recursos próprios nos orçamentos municipais, não supera 5\% do montante da receita arrecadada, na maioria dos casos, 
inviabiliza qualquer projeto de desenvolvimento, pois esta dependência torna passiva a sociedade local que não adquire as condições mínimas para organizar-se e gerir seu próprio destino.

Assim, a intenção deste autor era apontar caminhos para operar seu objetivo de primeiro, demonstrar as fragilidades na oferta dos serviços (documentos certificadores) e, segundo apontar opções de expansão dos serviços para a população, visando reduzir as dificuldades de acesso. Prado (2017) confirma em sua pesquisa que, para se atingir esse estágio de cidadania plena, muitas etapas ainda precisariam ser superadas. Para esse autor, com base na literatura, as políticas públicas de inclusão à cidadania foram os mecanismos utilizados nessa construção. Países como Itália, Suíça, Estados Unidos, França, Canadá, dentre outros, demonstram que foram e, ainda são utilizadas, as plataformas do próprio Estado ou outras plataformas públicas, como por exemplo, a de serviços postais - Correios, visando encurtar as distâncias e dar acesso à cidadania, para suas populações.

Autores como Osborn e Sund (2010) sustentam a tese pela qual um dos fatores mais relevantes para superar as barreiras de acesso à cidadania, nesses países, foi aproximar a infraestrutura do Estado dos cidadãos. Essa aproximação ocorreu basicamente de duas formas: pela criação de estruturas próprias do Estado ou pela utilização de plataformas públicas já existentes, sejam elas específicas ou múltiplas, presenciais ou virtuais, visando proporcionar alternativas de acesso dos cidadãos aos serviços, com maior conforto e comodidade.

Segundo estes autores, dentre as principais plataformas públicas utilizadas, estão a dos serviços postais (englobam atendimento e logística de distribuição). Para que isso possa acontecer, a rede postal tem sido modernizada, alcançando relevância nas últimas décadas, principalmente impulsionados pela União Postal Universal - UPU, organismo da Organização das Nações Unidas - ONU, para a integração postal. Nesse sentido, a Europa iniciou seu processo de transformação postal, no início dos anos 90, e tem impelido várias administrações do mundo a fazê-lo.

$\mathrm{Na}$ análise feita por Prado (2017), foi contemplada a população do estado da Bahia e a oferta de infraestrutura disponibilizada pelo Estado, para o acesso aos serviços certificadores de Registro Civil de Nascimento (RCN); Carteira de Identidade (CI); Cadastro de Pessoa Física (CPF) e; Carteira Nacional de Habilitação (CNH).

Diante da análise realizada por Prado (2017), e visando aprofundar ou atualizar o trabalho inicial desenvolvido, estabeleceu-se como questão de pesquisa para este trabalho de analisar se, além das plataformas públicas e da plataforma postal, a plataforma de serviços extrajudiciais pode ser também um instrumento que o Estado brasileiro dispõe, para ampliar a oferta de serviços de acesso a cidadania, com foco mais específico para o documento certificador "Carteira de identidade (CI)"?

A escolha desse documento em particular recai, principalmente, por alguns fatores específicos deste serviço, encontrados no trabalho de Prado (2017), a saber: a) trata-se de um documento fundamental para a cidadania; b) no estudo apresentou-se com uma grande lacuna em sua prestação; c) mostrou também que a responsabilidade de emissão cabe aos estados, e que em alguns estados a plataforma postal era utilizada para tanto. Porém, em outros estados assim como, no estado da Bahia, muitos municípios não contavam com a regularidade do serviço, ou seja, 59\% (244/417) dos municípios baianos.

Quanto aos demais serviços analisados por Prado (2017), o Registro Civil de Nascimento (RCN), em cujo estudo foram encontradas lacunas ou precariedade em 91 municípios, este parece ser uma etapa vencida visto que, no ano de 2017, houve a conclusão do primeiro concurso público de provas e títulos para prover os 1383 serviços extrajudiciais vagos do Estado da Bahia (TJBA, 2013). Desta forma, existem atualmente 501 serventias ativas, no Estado da Bahia, com atribuição de Registro Civil das Pessoas Naturais (CNJ, 2021), a quem a Lei de Registros Públicos (Lei no 6.015, de 31 de dezembro de 1973) confere a atribuição do registro de nascimentos. Verifica-se, portanto, que há um número de cartórios extrajudiciais aptos a realizar o registro de nascimento superior ao número de municípios (417), não havendo que se falar, portanto, em não prestação do serviço.

Quanto ao acesso do serviço de Cadastro de Pessoa Física (CPF), o qual o autor buscou mostrar como uma referência 
bem-sucedida de compartilhamento de plataformas (Correios, Banco do Brasil, Caixa Federal e outros), tem-se atualmente a integração dos Cartórios de Registro Civil de todo o país com a Receita Federal do Brasil. Em 16/05/2019 foi publicada a Instrução Normativa RFB n 1890, formalizando a realização de convênio entre a Associação Nacional dos Registradores de Pessoas Naturais (Arpen-Brasil) e a Receita Federal do Brasil, conforme o permissivo contido na Lei Federal no 13.484 de 2017, que classificou os Cartórios de Registro Civil das Pessoas Naturais como Ofícios da Cidadania.

Tal convênio permite que o cidadão baiano, desde julho de 2020, em qualquer uma das 501 serventias desta especialidade no estado da Bahia, tenha acesso aos serviços de inscrição, correção, alteração cadastral e emissão do comprovante de inscrição do CPF. A capilaridade dos serviços extrajudiciais ampliou o acesso do cidadão aos serviços inerentes ao CPF, simplificando a regularização cadastral e documental. Portanto, o que era caracterizado por esse autor como um serviço de referência, está sendo ainda mais fortalecido.

No tocante ao acesso do serviço de Carteira Nacional de Habilitação (CNH), mesmo que o trabalho de Prado (2017) tenha apontado inúmeras lacunas, dada a sua complexidade, entende-se que este, em especial, necessita de um estudo mais específico e detalhado, para ser analisado com maior profundidade.

Assim, a questão do trabalho irá recair sobre a análise ou a atualização da análise de Prado (2017), sobre o acesso ao serviço mais específico da Carteira de identidade (CI), pelas razões já expostas. Nesse sentido, o objetivo do trabalho é analisar a plataforma de serviços extrajudiciais, visando compreender quais os elementos (estruturais, legais e de recursos) que possui para facilitar o acesso à cidadania, com o serviço de Carteira de identidade (CI).

Para empreender este intento, o trabalho está assim configurado: esta introdução que contempla a contextualização, problematização, justificativa e objetivos, os métodos e procedimentos; cidadania no Brasil: acessos e descaminhos; o estado da Bahia e o acesso à cidadania - um sistema enigmático de difícil compreensão; as plataformas públicas podem ser as pontes de reconexão da cidadania; considerações finais e; referências.

\section{Métodos e Procedimentos}

A pesquisa possui natureza descritiva/exploratória, conforme Pádua (2016) e Estrela (2018), para a qual esta orientação busca esclarecer fenômenos ainda pouco conhecidos ou que, devido ao grau de complexidade e interligações, não estejam ainda muito claros. A metodologia utilizada foi o estudo de caso, a qual segundo Yin (2015) e Pereira et. al (2018), trata-se de uma descrição e análise, a mais detalhada possível, de fenômenos que apresentem alguma particularidade que os tornam especiais.

Indicam também esses autores que, sob o título de estudo de caso, se incluem muitos estudos, que formam uma gama de variedades. Normalmente, um caso para ser considerado como tal, deve ser um fenômeno que possui alguma característica especial ou diferencial, que o tira do "lugar comum". Neste caso, a cidadania, sob a perspectiva de acesso e desfrute, no estado da Bahia, com um recorte temporal que contempla a análise realizada por Prado (2017) e a atualização até o ano de 2021.

Cabe ressaltar que a construção da pesquisa foi alicerçada predominantemente sob o método qualitativo. Segundo Pereira et. Al (2018, p. 67), "este método é um caminho para se realizar alguma coisa e quando se tem o caminho, torna-se mais fácil realizar viagens sabendo onde se está e até onde se quer chegar e como fazê-lo". Os métodos qualitativos são aqueles nos quais é importante a interpretação por parte do pesquisador com suas opiniões sobre o fenômeno em estudo.

A operacionalização do estudo forjou-se em três etapas: Na primeira etapa, uma análise conceitual sobre os conceitos de modernidade e suas consequências, a cidadania social de Marshall (1967) e sua arenas de acesso e desfrute.

Na segunda etapa, uma análise sobre o trabalho de Prado (2017) a respeito do acesso e desfrute da cidadania no estado da Bahia, no qual este autor utilizou o conceito de fichas simbólicas adotado por Giddens (1991), analisando os documentos de acesso à cidadania (denominados pelo autor de documentos certificadores da cidadania). Nesta análise, Prado (2017) procurou 
demonstrar as lacunas de acesso à cidadania no estado da Bahia para quatro documentos certificadores (Registro Civil de Nascimento; Carteira de Identidade; Carteira Nacional de Habilitação e Cadastro de Pessoa Física), mostrando as inúmeras lacunas de acesso a esses serviços pela população baiana, apresentando a proposta de uso de plataformas públicas para minimizar essas carências, como os serviços postais.

$\mathrm{Na}$ terceira etapa, procurou-se trazer novos elementos ao trabalho de Prado (2017). Inclui-se o estudo sobre os projetos do Governo Digital (E-gov), no intuito de verificar quais os avanços destes mecanismos para oferta de serviços de acesso à cidadania. Buscou-se ainda analisar a plataforma de serviços extrajudiciais como entidades aptas a ampliar o acesso à cidadania, com foco no Estado da Bahia, onde os serviços extrajudiciais experimentaram grande transformação no ano de 2017, com a conclusão do primeiro concurso público para a atividade. Os serviços destinados a garantir publicidade, autenticidade, segurança e eficácia dos atos jurídicos (BRASIL, 1994) estão presente em todos os municípios baianos e é exatamente este atributo da capilaridade que os tornam elementos essenciais para o acesso e desfrute da cidadania.

Assim, desde o ano de 2017, pode-se afirmar que o serviço de Registro Civil de Nascimento é amplamente ofertado no Estado da Bahia. Desta forma, o serviço escolhido para a presente análise foi o documento certificador carteira de identidade, no âmbito do Estado da Bahia, pelo fato de constituir-se em um dos documentos mais relevantes para a cidadania, cuja emissão compete aos órgãos de identificação dos Estados e do Distrito Federal (BRASIL, 1983).

\section{Cidadania no Brasil - Acessos e Descaminhos}

Para Cortina (2005), a questão da cidadania trazida pela modernidade está replicada e atualizada, em seu assentamento sobre a tradição republicana e liberal dos dias de hoje, sendo própria das democracias participativas e representativas. Foram os ventos da modernidade soprando e, em seu âmago, o surgimento do Estado-Nação, que permitiram discutir e propiciar o aparecimento da questão da cidadania social, termo cunhado por Marshall (1967), em uma atualidade modernizada. Essa concepção pode ser vista na passagem a seguir:

A noção de cidadania que se converteu em padrão em nossos dias é a cidadania social, e Thomas Humphrey Marshall, que só o Estado de Bem-Estar conseguiu satisfazer, por mais deficiências que tenha apresentado. As dificuldades por que passa essa forma de Estado despertam sérias suspeitas de que as exigências apresentadas pela noção de cidadania social não vão diminuir. Um Estado de justiça parece tornar-se imprescindível. (CORTINA, 2005, p. 29).

Para esclarecer os fundamentos expostos por Cortina (2005), torna-se necessário utilizar o trabalho de Marshall (1967), o qual trouxe para o centro da discussão o que ele denominou de elementos centrais da cidadania, compostos por um conjunto de direitos que foram sendo adquiridos ou construídos pelas sociedades: os direitos civis (individuais), direitos políticos e direitos sociais (econômicos). Este autor afirma que o ponto de partida para o desenvolvimento da cidadania social foi a Revolução Inglesa de 1688, quando se estabeleceu naquele país a monarquia constitucional.

Para Marshall (1967), a cidadania deve ser um conceito nacional universalizante, por definição, pois o seu desenvolvimento implicou em um duplo processo de fusão e especialização. A fusão geográfica que ocorreu pelo surgimento do Estado-Nação, vindo produzir uma certa igualdade de direitos dentro de um mesmo território e a especialização como sendo um processo funcional, de modo que os três elementos (direitos civis, políticos e econômico ou sociais) viessem a tomar corpo, caminhos e ritmos próprios.

Segundo Marshall (1967, p. 28), "os conceitos centrais da cidadania estão fundados na igualdade, liberdade e autonomia de participação e gozo dos indivíduos”. Assim, na medida em que há um fortalecimento individual e local, tendem então a obter um caráter mais universalizante em seus territórios, definindo a cidadania social como sendo: "a lealdade de homens livres, imbuídos de direitos e protegidos por uma lei comum. Seu desenvolvimento é estimulado tanto pela luta para 
adquirir tais direitos quanto pelo seu gozo, uma vez adquiridos".

Na compreensão de Marshall (1967), em sua manifestação mais funcional, poderia retratar a aceitação de uma espécie de igualdade humana básica associada com um conceito de participação integral em uma determinada comunidade, a qual não se resume apenas a uma simples igualdade material, mas passa a ser compreendida como um vetor de igualdade de oportunidades.

Com isso, é possível que existam espaços políticos e institucionais, cujos níveis de "acesso" e "desfrute", tanto da cidadania do Bem-Estar quanto a cidadania social plena e universal de Marshall (1967), sejam mais equitativos ou mais desiguais, nas questões de integração dos indivíduos e coletividade, quando comparados a uma utopia universalizante de cidadania.

No Brasil, apesar de alguns avanços, há espectros de uma seletividade da sociedade brasileira, refletida sobre os conceitos de cidadania e subcidadania, trabalhados por Souza $(2000,2006,2011,2012)$, cujos fundamentos de sua análise estão centrados na discussão acerca da singularidade de algumas sociedades periféricas (como a brasileira), que se formaram ou se transformaram fundamentalmente a partir da expansão planetária do capitalismo moderno.

Assim, para esse autor, é possível perceber uma singular desproporção entre a análise das grandes culturas mundiais e os subcontinentes, como a América Latina por exemplo, constituída diretamente, pelo menos enquanto sociedades mais complexas, pela própria dinâmica da expansão ocidental.

Souza (2006) argumenta que as mazelas sociais existentes, principalmente em países periféricos como o Brasil, que sofrem com a desigualdade e sua naturalização, além de uma massiva marginalização de setores expressivos da população, e dificuldade de consolidação de uma ordem democrática e de mercado competitivo e eficiente, poderiam ser perfeitamente explicáveis a partir dessa expansão pré-moderna de modelos familísticos para todas as esferas sociais. Nesse contexto, a subcidadania seria um abismo material e valorativo entre classes e raças que compõem a sociedade brasileira.

Diante dessa realidade, a seletividade é um traço da construção da sociedade brasileira, sendo a subcidadania a sua consequência. Para Souza (2000), a cidadania é um estado parcial no Brasil. Muito embora no auge do afã democrático, pós 1985, com fim do regime militar no Brasil, foi elaborada a Constituição Federal de 1988, com o intuito de retomar a questão da cidadania e resgatar fundamentos perdidos. Para este autor, mesmo após 30 anos da Carta, isso ainda não foi possível plenamente. $\mathrm{O}$ aprimoramento do Estado e das instituições para a cidadania acontece ainda de maneira muito lenta.

Outra contribuição sobre a cidadania no Brasil parte de Holston (2013, p. 30), para o qual "a cidadania brasileira se caracteriza pela sobrevivência de seu regime de privilégios legalizados e desigualdades legitimadas". Nesses termos, o seu discurso se aproxima da interpretação de Souza (2006), porém gerando com sua análise duas categorias de cidadãos: os insurgentes (os subcidadãos) e os entrincheirados (os cidadãos). Para o insurgente, o excluído, cabe a luta por acesso e mais espaço (desfrute) de cidadania. Para o entrincheirado (o cidadão dos privilégios), a não perda de seus privilégios. $\mathrm{O}$ autor fundamenta esse aspecto peculiar da sociedade brasileira, caracterizando que o próprio termo cidadão era usado no Brasil, historicamente, como distanciamento ou anonimato. A passagem a seguir procura demonstrar essa realidade:

Usavam 'cidadão' para se referir à insignificante existência de alguém no mundo, em geral circunstância infeliz ou desvalorizada. Diziam que "aquele sujeito é um cidadão qualquer", o que significava "um ninguém". Faziam-no para deixar claro que a pessoa não era da família, nem amigo, nem vizinho, conhecido, colega, concorrente ou qualquer um que tivesse uma identidade familiar - para estabelecer, em suma, não apenas a ausência de uma relação pessoal, mas também a rejeição de uma relação comensurável que implicasse normas igualmente aplicadas. Cidadão indicava distância, anonimato e nada em comum. (Holston, 2013, p. 23).

Mesmo que Souza $(2000,2006,2011,2012)$ e Holston (2013) observem de forma tão particular essa situação da cidadania brasileira, e até possam tê-la enxergado em suas críticas, eles conduzem a um despertar sobre a necessidade de 
explorar alguns dos antecedentes históricos que conduziram o país a essa condição de cidadania seletiva.

\section{O Estado da Bahia e o Acesso à Cidadania - Um Sistema Enigmático de Difícil Compreensão}

Diante do que foi discutido sobre cidadania, cabe retomar a análise sociológica feita por Marshall (1967), pela qual definiu os elementos, arenas ou espaços da cidadania: os direitos civis, direitos políticos e direitos sociais (econômicos). Esses elementos na sociedade abrem os espaços para o exercício da cidadania, nos quais o cidadão vai obter o acesso, para só então ter o desfrute. Esses devem ser os espaços para os quais esse autor define a necessidade de haver uma igualdade humana básica, associada com o conceito de participação integral do indivíduo na sociedade.

Para Marshall (1967), esses espaços deveriam ser criados e garantidos pelo Estado-Nação - Estado Moderno - que, juntamente com seu conjunto de instituições, devem zelar pelo acesso e pelo desfrute das conquistas da cidadania. Assim, foi neste contexto do Estado Moderno, que as instituições se encarregaram de criar uma série de "fichas simbólicas", no sentido de Giddens, Beck e Lash (1997), ou um conjunto de procedimentos denominados por Prado (2017) como documentos certificadores (legitimadores da cidadania), para o reconhecimento do indivíduo como cidadão e, por meio deles, garantir o acesso e desfrute a cada um desses espaços.

Para Prado (2017), esse conjunto de fichas simbólicas ou documentos certificadores, visam garantir o acesso aos direitos fundamentais da cidadania: reconhecimento, acesso e desfrute. Primeiro, o indivíduo precisa ser reconhecido pelo Estado como cidadão, para posteriormente a esse evento, ter as garantias de desfrute.

É nesse sentido que os conceitos de seletividade de Souza (2001), e de insurgência de Holston (2013), são análises feitas sobre um processo histórico, o qual, para esses autores, o Estado brasileiro tem negado ou dificultado, tanto as formas de acesso, quanto o desfrute da cidadania. Essa construção ou conquista por uma sociedade passa, obrigatoriamente, primeiro, pelo reconhecimento e garantias legitimadoras do Estado; segundo, pela criação de mecanismos (políticas públicas) e procedimentos para o acesso e desfrute da cidadania; e terceiro, pelas garantias de convivência igualitária e integral, de forma irrestrita.

Assim, esse processo legitimador é que passaria pela aquisição do conjunto de documentos básicos (as fichas simbólicas) de acesso para a cidadania, aqui denominados de documentos certificadores. Para fundamentar essa visão, em trabalho realizado por Prado (2017), e reforçado por Prado, Souza, Reis e Spínola (2018 e 2020) e Prado, Santos e Serpa (2020), documentos certificadores é um termo cunhado para denominar um conjunto de documentos elementares para propiciar o acesso dos indivíduos às arenas ou conceitos da cidadania. Sem esses documentos, o indivíduo não terá acesso para desfrutar de sua condição mais básica como cidadão.

No estudo realizado por Prado (2017), utilizando o Censo Demográfico 2010, a área territorial do estado da Bahia está dividida em 417 municípios, e conta com uma população de 14.016.906 habitantes, ocupando a $4^{\mathrm{a}}$ posição no Brasil (IBGE, 2010). Possui uma extensão territorial de $564.831 \mathrm{Km}^{2}$, o que representa $6,6 \%$ do território brasileiro. Na Figura 1, pode-se ver a distribuição populacional no território do Estado (IBGE, 2010). 
Figura 1 - Bahia, População Residente nos Municípios, 2010.

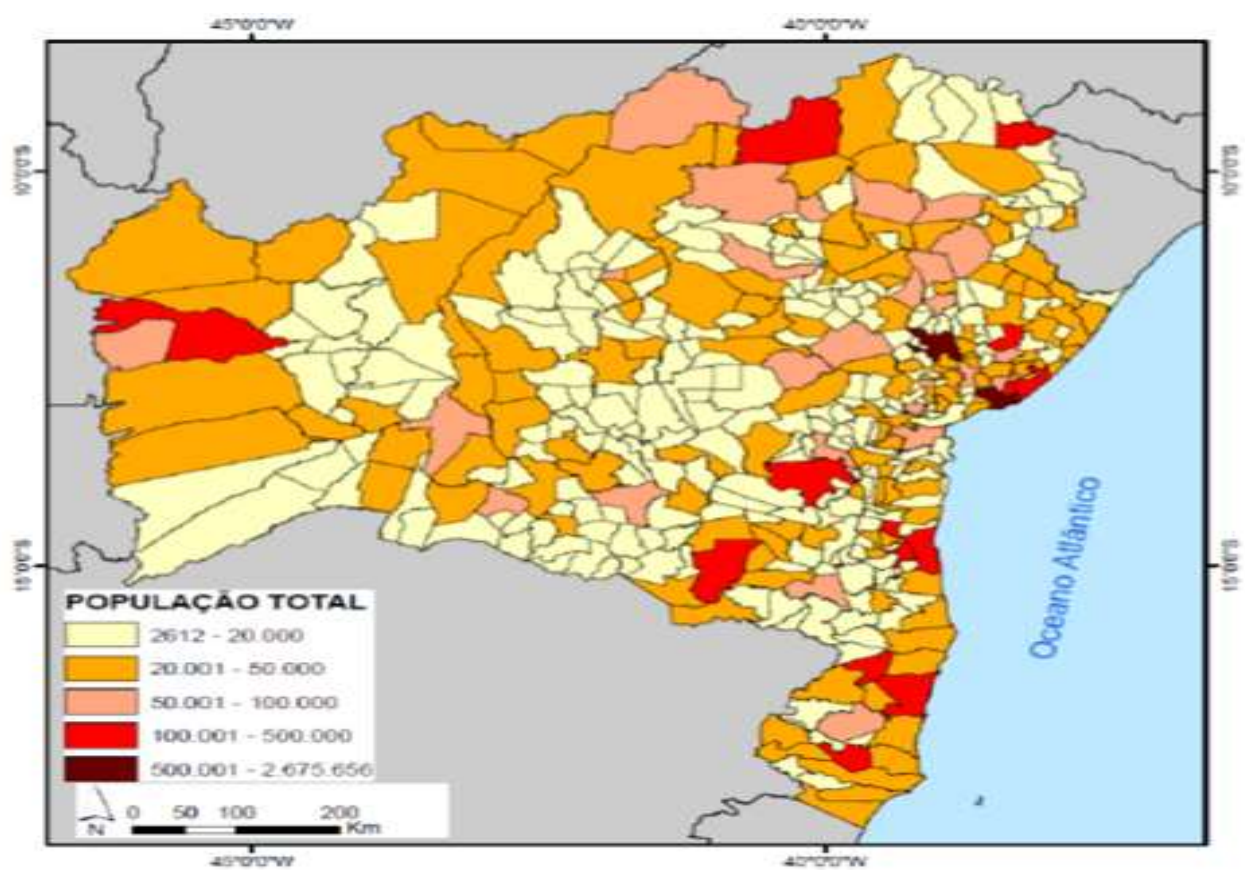

Fonte: Adaptado de Prado (2017).

Diante desta caracterização populacional do estado da Bahia, pretende-se agora analisar a infraestrutura de acesso ao serviço certificador para a cidadania de Carteira de Identidade (CI), disponibilizados pelo Estado, encontrada por Prado (2017), em seu trabalho (Figura 2). A CI constitui-se como um documento, cujo conjunto de características delimitadas legalmente, torna a pessoa um indivíduo único, diferenciando-o dos demais na sociedade.

Figura 2 - Mapa Bahia - Oferta do Serviço de CI - ano de 2016.

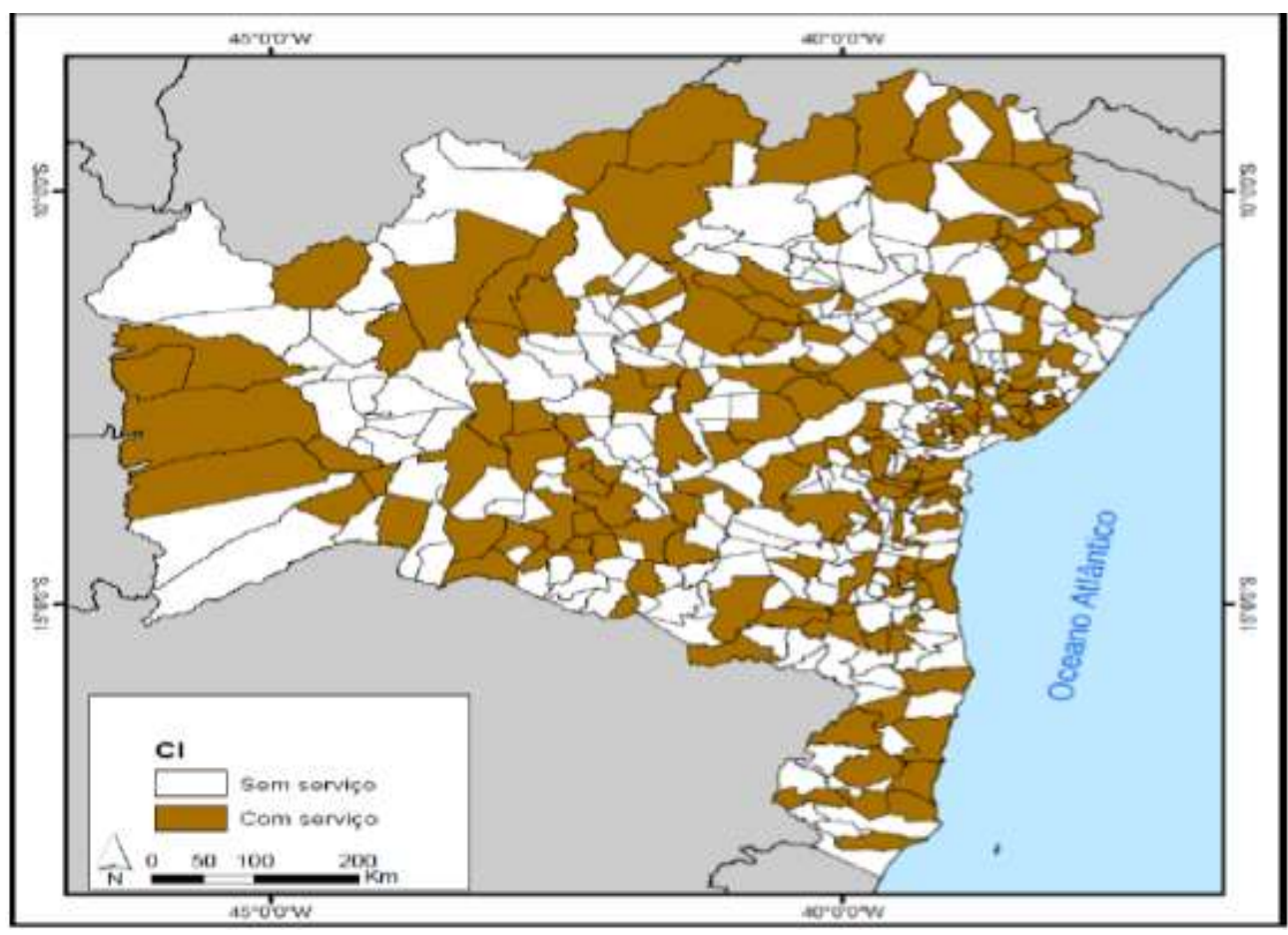

Fonte: Adaptado de Prado (2017). 
No Brasil, a Identificação Oficial (civil e criminal) é exercida pelos Órgãos de Identificação, vinculados às Secretarias de Segurança Pública, na sua maioria, no quadro da Polícia Civil, coordenado pelo Instituto Nacional de Identificação (INI), e descentralizada para os Estados, por meios de convênios.

De acordo com os dados obtidos junto à SSP-BA, para o serviço de CI no estado da Bahia, é possível verificar que $59 \%$ dos municípios (244/417) não possuem acesso. Relativo à população, para 28\%, ou seja, quase cinco milhões de pessoas (4.913.829/14.016.906), o serviço não é ofertado em seus municípios. As regiões Norte e Noroeste do estado apresentam as maiores lacunas na oferta desse serviço.

Na Figura 3, é possível verificar também a distribuição do serviço de CI e, no Gráfico 1, a distribuição e as distâncias percorridas pelos cidadãos, até as sedes de municípios com a oferta desse serviço.

Figura 3 -Mapa Bahia - localização das Sedes dos Municípios e o Serviço de CI - 2016.

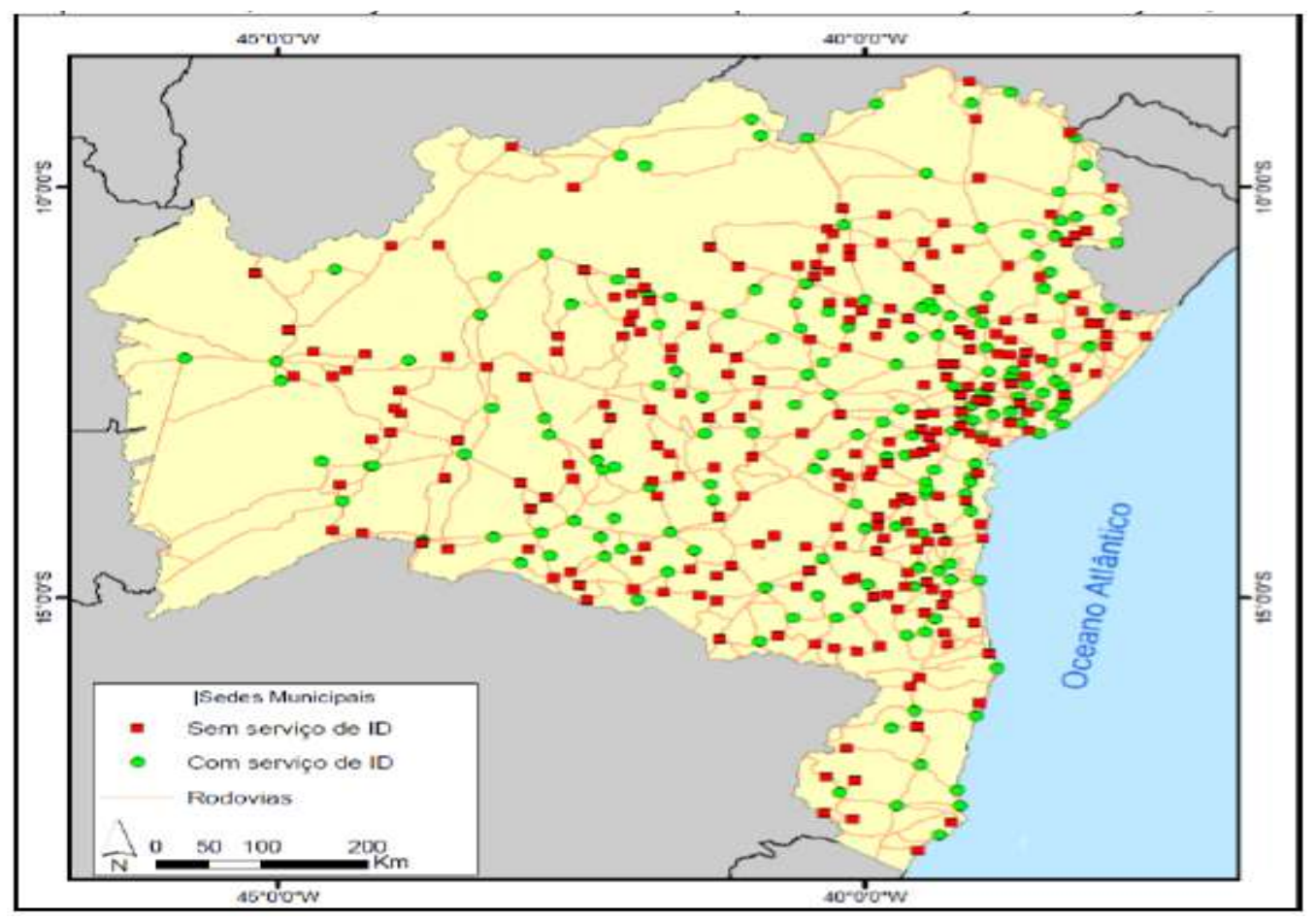

Fonte: Adaptado de Prado (2017).

Gráfico 1 - Bahia, distribuição dos serviços de CI a partir das Sedes dos Municípios, considerando a distância em quilômetros, 2016.

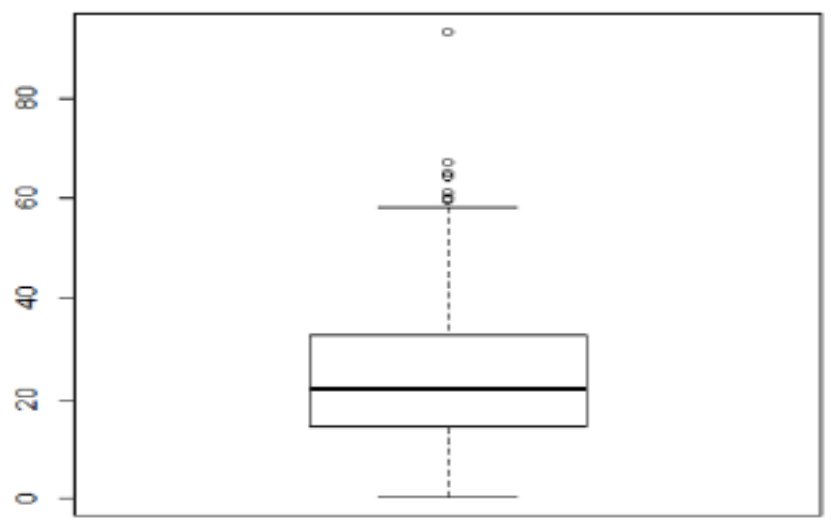

\begin{tabular}{|l|r|}
\hline \multicolumn{1}{|c|}{ ITEM } & \multicolumn{1}{c|}{$\begin{array}{c}\text { DISTĀANCIA } \\
\text { EM KM }\end{array}$} \\
\hline Mínima & 0.45 \\
\hline $\mathbf{1}^{\circ}$ quartil & 14.48 \\
\hline Mediana & 21.95 \\
\hline Média & 25.10 \\
\hline $3^{\circ}$ quartil & 32.48 \\
\hline Máximo & 93.30 \\
\hline
\end{tabular}

Fonte: Adaptado de Prado (2017). 
Nesse sentido, quando a análise realizada por Prado (2017) recai sobre as questões de onde se localizam e quais condições possuem os municípios em que são ofertados os serviços, o autor levou em conta duas variáveis: o IDHM e o PIB.

Quando se observa a relação entre a oferta dos serviços e o Índice de Desenvolvimento Humano Municipal - IDHM, verifica-se que são 103 municípios do estado da Bahia classificados pelo ranking PNUD (2013), como de muito alto desenvolvimento. Dentre esses, 93 disponibilizam o serviço de acesso à CI, representando 90\% desses municípios. Cabe ainda ressaltar que desse grupo, apenas 10 não possuem a oferta deste serviço. Portanto, pode-se inferir que as melhores condições de desenvolvimento social estão concentradas, e por sua vez possuem a melhor infraestrutura de oferta de serviços à população, e em consequência as melhores condição de acesso à cidadania.

Por outro lado, dos 106 municípios classificados pelo PNUD (2013) como de baixo IDHM, 62 (59\%) não possuem acesso ao serviço. Isso configura um quadro em que a infraestrutura ofertada para os municípios mais carentes é mais precária, e que pode influenciar direta e indiretamente no desenvolvimento social ou bem-estar de suas populações. Diante desse contexto, podem ser observadas algumas das consequências mais imediatas desta triste realidade de restrições ao aceso à cidadania.

Em sua análise geral, Prado (2017) constatou que são 91 municípios no estado da Bahia que não possuem a prestação de nenhum dos três tipos de serviços por ele analisados. Esses municípios representam apenas $4 \%$ do PIB baiano. Nesse caso, é possível inferir que a infraestrutura de atendimento está mais concentrada nas regiões com um maior peso econômico, distanciando, portanto, os municípios com maiores carências, tornando-os mais distantes dos centros econômicos e das facilidades de acesso à cidadania. Cabe ressaltar que $90 \%$ dos municípios baianos possuem até 50 mil habitantes, o que agrava ainda mais o quadro atual.

Quando se analisa o serviço de CI, percebe-se que, entre os 37 municípios formadores dos 2/3 do PIB baiano, somente 1 município não possui acesso direto ao serviço. Todos os demais são contemplados. Porém, ao se analisar os 100 municípios com menor participação no PIB, apenas 20 (20\%) ofertam esse serviço à população. Relação semelhante é mantida quando se analisa a oferta de serviço de CI com o IDHM. Nos 100 municípios com os menores índices de IDHM, 25 (25\%) recebem a oferta de serviço. Mais uma vez se percebe a concentração da infraestrutura desse serviço, nos municípios mais dinâmicos economicamente.

Com a análise feita por Prado (2017), ficaram evidenciadas as dificuldades de acesso aos documentos certificadores, que irão permitir a transformação de indivíduos em cidadãos. Quando se pensa nesta lacuna, torna-se possível imaginar que, sem acesso ou com as enormes dificuldades existentes, o desfrute pleno verifica-se inacessível. Porém, nem tudo pode ser visto pelo lado catastrófico. Há luz no final do túnel.

As análises sintéticas emprestadas por Prado (2017) remetem a uma necessária análise sobre quais ações o Estado ou Governos, podem adotar para permitir uma maior igualdade de acesso à cidadania, visando que o desfrute possa ser mais equilibrado. Assim, passa-se a analisar o projeto de e-governo e sua promessa de plataforma para a cidadania, bem como observar e descrever a plataforma postal e a plataforma de serviços extrajudiciais, visando poder comparar as possibilidades de diminuir os vazios existentes para o acesso à cidadania no Estado da Bahia.

\section{As Plataformas Públicas podem ser as Pontes de Reconexão da Cidadania?}

Em um cenário pouco animador, o Estado brasileiro tem procurado ofertar acesso à cidadania de forma mais ampla $\mathrm{e}$ democrática para todos os cidadãos, tendo como iniciativa o projeto do Governo Digital (E-Gov). O Governo Digital consiste no uso de plataformas públicas que visam dinamizar e modernizar os serviços ofertados aos cidadãos. A modernização e digitalização do estado relaciona-se com a necessidade de uma maior transparência na gestão econômica e fiscal da operação pública, por uma busca da eficiência, eficácia e efetividade na prestação de serviços e na melhoria contínua da qualidade dos 
serviços ofertados aos cidadãos. Esses fatores podem colaborar no processo da democratização política, social e civil, contribuindo para o crescimento da legitimação de governos e estabelecer novas formas de gerenciamento das atividades públicas. Nesse sentido é relevante analisar a plataforma do E-Gov e a sua linha do tempo (cronologia) dentro do projeto do governo eletrônico.

No Brasil, a implantação de um Governo Digital vem ocorrendo desde o ano 2000, com a proposta de transparência da gestão pública e disponibilização do portal da transparência. Na Figura 4 é possível visualizar essa ação:

Figura 4 - Linha do Tempo do Governo Eletrônico.

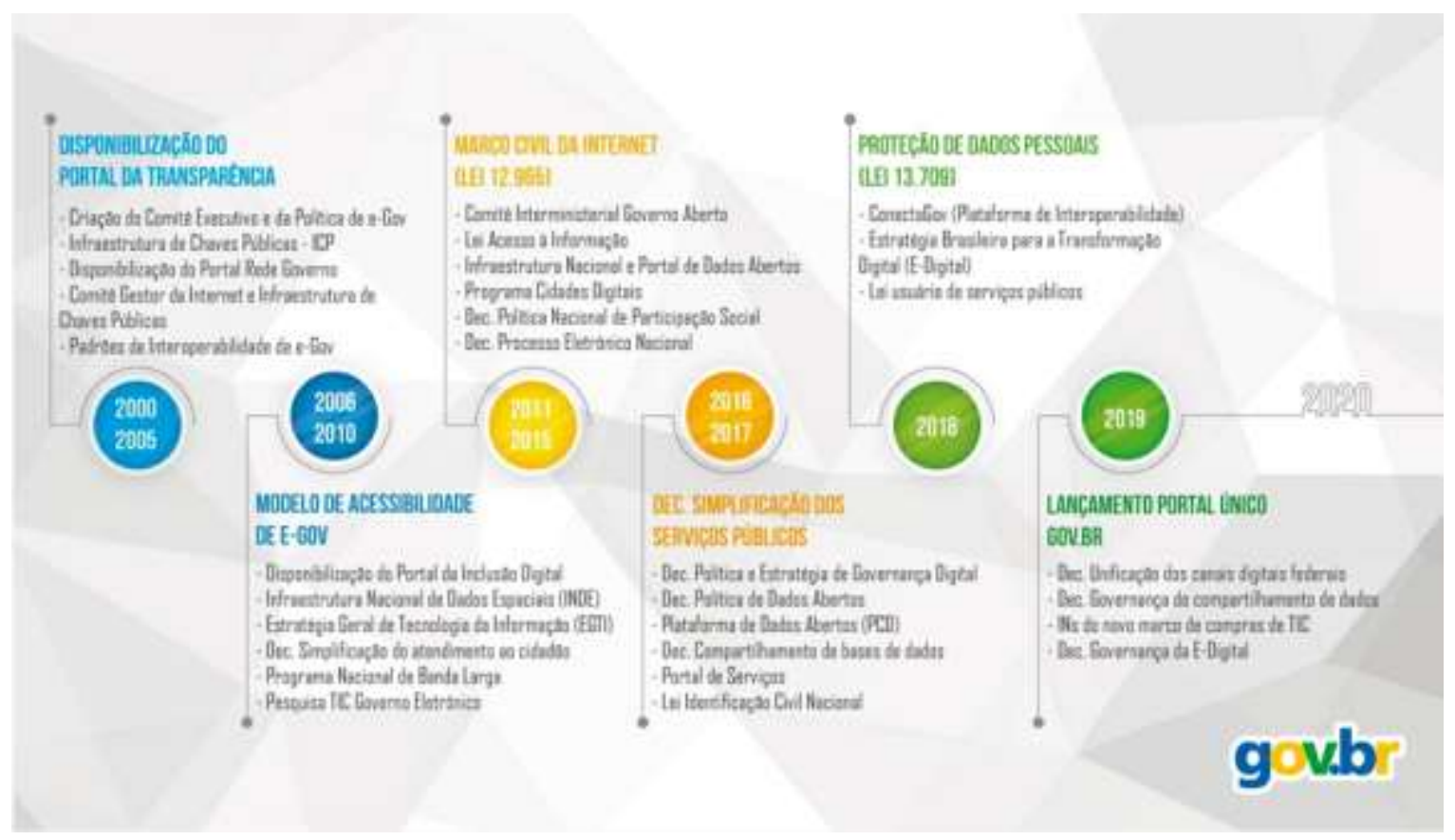

Fonte: https://www.gov.br/governodigital/pt-br/estrategia-de-governanca-digital/do-eletronico-ao-digital.

No Quadro 1, cronologicamente está contemplado o conjunto de ações desenvolvidos pelos governos para a implantação da plataforma do Governo Digital (o E-gov), visando facilitar, entre outras coisas, o acesso à cidadania no Brasil.

Quadro 1 - Conjunto de Ações do Governo Federal para o E-Governo.

\begin{tabular}{|c|c|}
\hline ANO - PROJETO & AÇÃOO \\
\hline 2000 a 2005 & $\begin{array}{l}\text { Criação do Comitê Executivo e da Política de E-Gov: O Grupo de Trabalho em Tecnologia da Informação (GTTI), } \\
\text { formalizou-se pela Portaria da Casa Civil } n^{\circ} 23 \text { de } 12 \text { de maio de } 2000 \text {, e suas ações foram incorporadas às metas do } \\
\text { programa Sociedade da Informação, sob coordenação do Ministério da Ciência e Tecnologia. O GTTI esforçou-se para } \\
\text { a universalização de serviços; o governo ao alcance de todos e uma infraestrutura avançada e conectada. O Decreto de } \\
18 \text { de outubro de } 2000 \text {, criou o Comitê Executivo de Governo Eletrônico (CEGE), com o objetivo de estabelecer } \\
\text { diretrizes, metas e realizar a implantação do E-Gov. } \\
\text { Infraestrutura de Chaves Públicas - ICP: Consiste em uma cadeia hierárquica confiável que viabiliza a emissão de } \\
\text { certificados digitais para a identificação virtual do cidadão. A Medida Provisória } 2200 \text {, de } 28 \text { de junho de } 2001 \text {, criou } \\
\text { a ICP-Brasil. O Decreto no } 3697 \text {, de } 21 \text { de dezembro de } 2000 \text {, regulamentou o pregão eletrônico no âmbito da } \\
\text { administração federal. } \\
\text { Disponibilização do Portal Rede Governo: Através do Decreto de } 04 \text { de dezembro de } 2001 \text {, criou-se o Subcomitê da } \\
\text { Rede Brasil.gov, com o objetivo de planejar e deliberar a gestão do projeto de integração das diversas redes de } \\
\text { comunicação de dados do governo federal. }\end{array}$ \\
\hline Disponibilização do portal da & $\begin{array}{l}\text { Comitê Gestor da Internet e Infraestrutura de Chaves Públicas: A Portaria Interministerial no } 147 \text {, de } 31 \text { de maio de } \\
\text { 1995, cria o Comitê Gestor da Internet no Brasil. O Decreto } n^{\circ} 4829 \text {, de } 3 \text { de setembro de } 2003 \text {, dispõe sobre o modelo }\end{array}$ \\
\hline
\end{tabular}




\begin{tabular}{|c|c|}
\hline transparência & $\begin{array}{l}\text { de governança da internet no Brasil e sua relação com o ICP-Brasil. } \\
\text { Padrões de Interoperabilidade de E-Gov: A Portaria Normativa } n^{\circ} 05 \text {, de } 14 \text { de julho de 2005, institucionaliza os } \\
\text { Padrões de Interoperabilidade de Governo Eletrônico. A arquitetura de Padrões de Interoperabilidade (e-PING), define } \\
\text { um conjunto de políticas, premissas e especificações técnicas que regulamentam a utilização da Tecnologia de } \\
\text { Informação e Comunicação no governo federal, disponibilizando as condições de interação com os demais poderes e } \\
\text { esferas de governo com a sociedade. }\end{array}$ \\
\hline $\begin{array}{l}2006 \text { a } 2010 \\
\text { Modelo de Acessibilidade de } \\
\text { E-Gov }\end{array}$ & $\begin{array}{l}\text { Disponibilização do Portal da Inclusão Digital: Ativo em 2006. Atualmente encontra-se fora do ar. Seu objetivo } \\
\text { central era estabelecer ações para as comunidades carentes. O Decreto } n^{\circ} 5542 \text {, de } 20 \text { de setembro de } 2005 \text {, institui o } \\
\text { Projeto Cidadão Conectado - Computador para Todos, no âmbito do Programa de Inclusão Digital. } \\
\text { Infraestrutura Nacional de Dados Espaciais (INDE): Instituída pelo Decreto no } 6666 \text { de } 27 \text { de novembro de } 2008 \text {. Seu } \\
\text { propósito é o de catalogar, integrar, e organizar dados geoespaciais produzidos ou mantidos pelo governo federal. } \\
\text { Estratégia Geral de Tecnologia da Informação (EGTI): Instituída pela Portaria SLTI (Secretaria de Logística e } \\
\text { Tecnologia da Informação) no } 11 \text {, de } 30 \text { de dezembro de } 2008 \text {. Seu objetivo é o de estabelecer as bases para a transição } \\
\text { entre a situação da gestão dos ambientes de informática do Executivo Federal (heterogênea e em geral vulnerável), } \\
\text { conforme apontado no Acórdão no } 1603 / 2008 \text { TCU Plenário e o pleno cumprimento da Instrução Normativa SLTI no } \\
\text { 04/2008. } \\
\text { Decreto de Simplificação do Atendimento ao Cidadão: O Decreto no } 6932 \text {, de } 11 \text { de agosto de } 2009 \text {, dispõe sobre a } \\
\text { simplificação do atendimento público prestado ao cidadão, ratifica a dispensa do reconhecimento de firma em } \\
\text { documentos produzidos no Brasil e institui a "Carta de Serviços ao Cidadão". } \\
\text { Programa Nacional de Banda Larga: O PNBL foi criado pelo Decreto no } 7175 \text { de } 12 \text { de maio de } 2010 \text {, com o objetivo } \\
\text { principal de massificar o acesso à internet de banda larga em todo o país, principalmente nas regiões mais carentes } \\
\text { dessa tecnologia. }\end{array}$ \\
\hline $\begin{array}{l}\qquad 2011 \text { a } 2015 \\
\text { Marco Civil da Internet (Lei } \\
\text { 12965) }\end{array}$ & $\begin{array}{l}\text { Comitê Interministerial Governo Aberto: O Decreto de } 15 \text { de setembro de } 2011 \text {, institui o Plano de Ação Nacional } \\
\text { sobre Governo Aberto, destinado a promover medidas e ações que buscam o incremento da transparência e do acesso à } \\
\text { informação pública, melhoria na prestação dos serviços públicos e o fortalecimento da integridade pública. Fica } \\
\text { instituído o CIGA - Comitê Interministerial Governo Aberto, composto por diversos órgãos do governo federal. } \\
\text { Lei Acesso à Informação: A Lei no } 12527 \text {, de } 18 \text { de novembro de } 2011 \text {, regula o acesso a informações previsto na } \\
\text { Constituição Federal. } \\
\text { Infraestrutura Nacional e Portal de Dados Abertos: A INDA - Infraestrutura Nacional de Dados Abertos é um } \\
\text { conjunto de tecnologias, padrões, procedimentos e mecanismos de controle que são necessários para atender as } \\
\text { condições de compartilhamento de dados e informações públicas em conformidade com o disposto na e-PING. } \\
\text { Instituída pela Instrução Normativa no } 4 \text {, de } 12 \text { de abril de } 2012 \text {. } \\
\text { Programa Cidades Digitais: O programa promove a inclusão digital nos municípios com foco na melhoria da } \\
\text { qualidade dos serviços e da gestão pública, por meio de instalação de redes, pontos públicos de acesso à internet, } \\
\text { sistemas de gestão na área pública e capacitação. A Portaria n } 376 \text {, de } 19 \text { de agosto de } 2011 \text {, institui o programa. } \\
\text { Decreto Política Nacional de Participação Social: O Decreto no } 8243 \text {, de } 23 \text { de maio de } 2014 \text {, institui a Política } \\
\text { Nacional de Participação Social (PNPS) e o Sistema Nacional de Participação Social (SNPS), com o objetivo de } \\
\text { fortalecer e articular os mecanismos e instâncias democráticas de diálogo e atuação conjunta entre a administração } \\
\text { pública e a sociedade civil. }\end{array}$ \\
\hline $\begin{array}{l}\text { Decreto Simplificação dos } \\
\text { Serviços Públicos }\end{array}$ & $\begin{array}{l}\text { Decreto Política e Estratégia de Governança Digital } \\
\text { Decreto Política de Dados Abertos } \\
\text { Plataforma de Dados Abertos (PCD) } \\
\text { Decreto Compartilhamento de Bases de Dados } \\
\text { Portal de Serviços } \\
\text { Lei Identificação Civil Nacional: }\end{array}$ \\
\hline 2018 & $\begin{array}{l}\text { ConectaGov (Plataforma de Interoperabilidade) } \\
\text { Estratégia Brasileira para a Transformação Digital (E-Digital) }\end{array}$ \\
\hline
\end{tabular}




\begin{tabular}{|c|l|}
\hline $\begin{array}{c}\text { Proteção de Dados Pessoais } \\
\text { (Lei 13709) }\end{array}$ & Lei Usuário de Serviços Públicos: \\
\hline 2019 & $\begin{array}{l}\text { Decreto Unificação dos Canais Digitais Federais } \\
\text { Decreto Governança do Compartilhamento de Dados } \\
\text { INs do Novo Maro de Compras de TIC } \\
\text { Decreto Governança da E-Digital: }\end{array}$ \\
$\begin{array}{c}\text { Lançamento Portal Único } \\
\text { GOV.BR }\end{array}$ & \\
\hline
\end{tabular}

Fonte: Adaptado de https://www.gov.br/governodigital/pt-br/estrategia-de-governanca-digital/do-eletronico-ao-digital (2021).

Diante das ações verificadas no Quadro 1, ficam evidenciadas que, mesmo precárias, ainda residem muito no campo legal. A transposição deste campo para sua implementação e desfrute deverá ter um caminho longo ainda a ser percorrido. Enquanto isso, a cidadania precária de acesso e desfrute vai se distanciando do indivíduo comum e se concentrando em locais com melhor infraestrutura (por localização, investimentos etc.). Diante dessa realidade, ficam mais evidentes a necessidade de utilização de outros mecanismos, já sinalizados pelo estudo de Prado (2017) e, agora mais recentemente, pela estruturação no estado da Bahia dos serviços extrajudiciais. Nesse contexto, antes de adentrar na ascensão dos serviços extrajudiciais, cabe ainda deixar mais clara a proposta de Prado (2017) sobre a plataforma postal.

Para esse autor, a plataforma postal é formada nacionalmente por um conjunto de pontos de atendimento, integradas por uma rede de comunicação e logística, presente em todos os municípios brasileiros. Mundialmente, congrega uma rede de 192 países, coordenada pela União Postal Universal - UPU, braço das Organizações das Nações Unidas - ONU, para coordenar a rede de serviços postais - aqui denominada de plataforma de serviços postais.

Os fatores considerados importantes são a infraestrutura e presença, disponibilizada em todo o território nacional. Com dados obtidos dos Relatórios de Gestão Empresarial - RAE, 2014, 2015, 2016 e 2017, os Correios contavam em seus quadros com mais de 100 mil empregados. Em sua rede de atendimento são 6.501 agências próprias e 6.626 agências operadas por terceiros (sob as diversas formas jurídicas); mais de 9 mil caixas de coleta e mais de mil postos de vendas de produtos. A rede logística possui 10.524 unidades operacionais e conta com uma frota de 25.236 veículos e 13 linhas postais aéreas noturnas. Essa estrutura distribuiu 8,5 bilhões de objetos em 2014 e 8,3 bilhões em 2015. Perfazendo um total de 34,5 e 33,2 milhões de objetos por dia, respectivamente. No estado da Bahia, a plataforma postal é composta por mais de 530 agências, presente em todos os munícipios.

No tocante às experiências de trabalhos em parceria com os governos das esferas federal, estadual e municipal, e outros organismos nacionais e internacionais, cabe ressaltar, principalmente, de acordo com os dados publicados por Prado (2017), que a empresa já realiza alguns grandes projetos na execução de políticas e políticas públicas para a cidadania: a) distribuição de 90 toneladas de livros didáticos (157 milhões de livros) para 147 mil escolas, com 37 milhões de alunos envolvidos, em parceria com o Fundo Nacional de Desenvolvimento da Educação (FNDE), projeto 2014/2015; b) operação Exame Nacional do Ensino Médio (ENEM), com a distribuição de 19,3 milhões de provas em 17.849 escolas, alcançando 1.751 municípios e; c) projeto eleições, em alguns Estados da federação, com a distribuição e coleta de 436.256 urnas eletrônicas, mais de 33.849 objetos de apoio à logística, movimentando aproximadamente 15.444 profissionais e 4.692 veículos. Nos anos de 2015/2016 executaram a logística oficial dos jogos olímpicos no Rio de Janeiro, como operador oficial dos jogos.

Em projetos de menor envergadura, mas não menos importantes, executam ou já foram executados serviços à cidadania em vários estados e munícipios da Federação. Aqui serão apresentados alguns exemplos: a) distribuição de medicamentos (remédio em casa) em parcerias com os governos estaduais e municipais de São Paulo e Rio de Janeiro; b) facilidades de acesso à justiça, em plataformas tecnológicas comuns e serviços de atendimento especial e logística, para envio de petições iniciais e documentos referentes a processos judiciais, nos estados de Santa Catarina, Rio Grande do Sul, Espírito 
Santo e Paraná; c) serviço de solicitação e recebimento de passaporte, em parceria com a Polícia Federal, em todo o território nacional; d) solicitação de Cadastro de Pessoa Física (CPF) nas agências dos Correios, parceria com a Receita Federal, em todo o território nacional e; soluções completas para o trânsito em estados como Rio Grande do Sul, São Paulo e soluções parciais em outros estados como Bahia, Goiás etc.

Assim, com sua extensa plataforma de atendimento e rede logística, torna-se viável a condição dos Correios, para serem um agente catalisador de políticas públicas para a cidadania, ampliando muito a capacidade do Estado e Governos de estender os limares de oferta de serviços para o acesso e desfrute da cidadania no Brasil, disponibilizando uma estrutura pública já existente, oferecendo maior acesso, conforto, comodidade e menor custo aos cidadãos, desde que respeitados ou superados alguns limites hoje existentes na instituição.

É possível, diante disso, observar nas infraestruturas de oferta de serviços dos Estados e Municípios, diferenças enormes na disponibilização à sociedade. O IDHM pode ser um índice que represente essas realidades distintas. Podem ser vistos indicadores como PIB, renda per capita, saúde, educação, acesso à internet, dentre outros, tão dispares quando se compara, no Brasil, as diversas entidades da Federação. Portanto, o alerta aqui trazido, por conta desses fatores, carece de uma análise mais profunda de técnicos da empresa e do Estado, visando planejar legislação e políticas públicas que sejam compatíveis entre elas e que visem encurtar as distâncias entre cidadania e isolamento (subcidadania).

A questão do fator de segurança pode ser um grande limitador. Apesar dos avanços tecnológicos, existem pontos que precisam ser observados tanto na concepção dos sistemas, quanto na execução dos serviços. Esse ponto, na relação Correios e políticas públicas, é também crucial. Diante disso, assim como a questão de legislação, a questão de segurança na prestação dos serviços precisa ser pensada na origem do planejamento das políticas públicas e deve estar contida na gestão dos Correios, tanto no desenvolvimento de soluções (produtos/serviços), quanto na sua execução.

Outro fator é a remuneração dos Correios pelo serviço prestado. Neste ponto precisa ser discutido quem arcará com o ônus do serviço: o cidadão ou o Estado. Esses pontos aqui trazidos têm o intuito de demonstrar a existência de uma série de fatores que precisam ser observados e trabalhados, quando da inclinação de tornar os Correios uma instituição catalisadora para as políticas públicas de cidadania no Brasil. Porém, são inegáveis as possibilidades de ampliação da oferta de serviços à sociedade brasileira pelo Estado e governos, utilizando as plataformas de atendimento e logística dos Correios. Isso já foi vivenciado em países considerados desenvolvidos e está sendo vivenciados em muitos países em desenvolvimento (China, Índia, Rússia, África do Sul e outros), inclusive em diversos entes públicos (Federação, Estados e Munícipios) no Brasil, embora de forma fragmentada.

No tocante a plataforma de serviços postais, fica evidente que pode ser utilizada pelos governos para melhorar o acesso e desfrute da cidadania no Brasil e na Bahia. Assim, cabe ainda a necessidade de explorar outras plataformas que estão disponíveis, principalmente no estado da Bahia, para servir a esta finalidade. Neste ponto, cabe um olhar mais cuidadoso sobre a plataforma de serviços extrajudiciais.

As serventias extrajudiciais estão diretamente relacionadas ao acesso à cidadania, em virtude dos atos que praticam. Quando se fala em garantia de cidadania por meios dos cartórios extrajudiciais, é usual identificar uma vinculação imediata aos Cartórios de Registro Civil das Pessoas Naturais, que conforme se verá adiante, possuem atualmente a qualificação de Ofícios da Cidadania. Porém, os atos garantidores da cidadania não são apenas os registros de nascimento e óbito, mas também diversos outros atos, de competência das demais atribuições, que abrangem os Tabelionatos de Notas, os Tabelionatos de Protesto, os Registros de Imóveis, os Registros Civis das Pessoas Jurídicas e os Registros de Títulos e Documentos.

Instrumentos de desjudicialização, os cartórios extrajudiciais viabilizam a concretização dos direitos mais fundamentais e elementares do cidadão, garantindo a tão almejada dignidade da pessoa humana. Ocorre que, no estado da Bahia, os cartórios extrajudiciais possuem um triste e peculiar histórico, que ainda hoje é diariamente combatido na memória 
da população. É possível afirmar que, somente após o ano de 2017, os cartórios extrajudiciais do Estado da Bahia podem de fato ser vistos como um meio de acesso à cidadania.

Neste contexto, um dos fatores que contribuiu para a conhecida fragilidade no acesso à cidadania por parte da população baiana se relaciona com o peculiar histórico das serventias extrajudiciais neste estado da federação. Os cartórios, como assim são conhecidos pela população em geral, foram oficializados na Bahia no ano de 1979, por meio da Lei Estadual $\mathrm{n}^{\circ}$ 3.731, que dispõe sobre a organização judiciária. Dizer que os cartórios foram oficializados significa que eles eram integrantes do Poder Judiciário, administrados, portanto, pelo Tribunal de Justiça, nos quais atuavam os respectivos servidores públicos.

Com a promulgação da Constituição da República em 1988, a chamada Constituição Cidadã, os serviços notariais e de registro foram disciplinados em seu artigo 236, cuja regulamentação ficou a cargo da Lei $\mathrm{n}^{\circ}$ 8.935, de 18 de novembro de 1994. A atividade possui natureza pública, porém, sua execução é delegada ao particular que é aprovado em concurso público de provas e títulos. Este particular não é servidor público e sim um agente particular em colaboração com o Poder Público, conforme definido por Di Pietro (2014).

Exercem tal atividade os tabeliães de notas, os tabeliães e oficiais de registro de contratos marítimos, os tabeliães de protesto de títulos, os oficiais de registro de imóveis, os oficiais de registro de títulos e documentos e civis das pessoas jurídicas; os oficiais de registro civis das pessoas naturais e de interdições e tutelas, e os oficiais de registro de distribuição (BRASIL, 1994).

Em que pese a previsão constitucional no sentido de tornar privada a gestão das serventias extrajudiciais, o Estado da Bahia permaneceu com seus cartórios administrados por servidores públicos até o ano de 2011. Em verdade, o Estado da Bahia descumpriu a Constituição Federal por mais de 20 anos, fato este que implicou em grande prejuízo para sua população, que enfrentou dificuldades extraordinárias para ter acesso aos documentos certificadores, ou seja, para ter o acesso e desfrute da cidadania plena. De certa maneira o trabalho de Prado (2017), procurou demonstrar essa realidade.

No ano de 2011 ocorre a publicação da Lei Estadual nº 12.352, que classifica os serviços extrajudiciais como atividade privada, a ser delegada pelo Poder Público e fiscalizada pelo Tribunal de Justiça. Ocorre que a mencionada lei não proporcionou, na realidade, a privatização das serventias oficializadas, visto que não resultou na publicação de concurso público de provas e títulos para a atividade extrajudicial, nos moldes do artigo 236 da Constituição Federal. $\mathrm{O}$ artigo $2^{\circ}$ da Lei Estadual $\mathrm{n}^{\circ}$ 12.352, que inclusive é objeto de ação direita de inconstitucionalidade perante o Supremo Tribunal Federal (ADI 4851 BA), concedeu o direito de opção aos servidores públicos, em permanecer na condição de servidores estatutários, remunerados pelo Poder Judiciário, ou titularizar, de forma privada, as serventias extrajudiciais:

Art. $2^{\circ}$ - É facultada aos servidores legalmente investidos na titularidade das serventias oficializadas a opção de migrar para a prestação do serviço notarial ou de registro em caráter privado, na modalidade de delegação instituída por esta Lei.

$\S 1^{\circ}$ - Os notários e registradores das serventias oficializadas, caso não optem pela condição de delegatários, permanecerão regidos pelas normas aplicáveis aos servidores públicos, sendo-lhes assegurados todos os direitos adquiridos, hipótese em que ficarão à disposição do Tribunal de Justiça do Estado da Bahia que lhes designará função compatível com aquela para a qual prestaram concurso público.

(...)

$\S 4^{\circ}$ - A opção referida no caput deverá ser manifestada por meio de requerimento dirigido ao Presidente do Tribunal de Justiça, no prazo de 120 (cento e vinte) dias, a contar da data da publicação desta Lei.

$\S 5^{\circ}$ - A ausência de requerimento no prazo assinalado no $\S 4^{\circ}$ implicará na opção pela continuidade na condição de servidor público. 
Após a publicação da Lei Estadual n ${ }^{\circ}$ 12.352, em 08 de setembro de 2011, somente pouco mais de 140 serventias passaram a ser administradas de forma privada pelos servidores públicos, que realizaram a opção descrita no parágrafo $4^{\circ}$ do artigo $2^{\circ}$, permanecendo oficializadas todas as demais. O retrato da atividade extrajudicial no estado era caótico: a população, ao invés de ter acesso aos serviços que deveriam ser prestados para garantir sua condição de cidadão, eram sujeitos a dormir em filas, em situação degradante e frontalmente contrária à dignidade da pessoa humana.

A privatização de fato das serventias baianas ocorreu somente no ano de 2017, com a conclusão do primeiro concurso público de provas e títulos, para prover as 1383 serventias vagas no estado. A partir de então, a história do extrajudicial no estado da Bahia começou a ser devidamente escrita, com o protagonismo de delegatários devidamente habilitados para o exercício da função, apresentando uma nova realidade para os cidadãos baianos, que passaram a vivenciar um novo cenário no que se refere ao acesso à cidadania.

Sobre as diversas especialidades dos serviços notariais e de registro e sua relação com o acesso a cidadania, cabe registrar que os serviços notariais e de registro estão dentre as instituições brasileiras dotadas de maior confiabilidade por parte da população, conforme pesquisa realizada pelo Datafolha, a pedido da Anoreg-BR, no ano de 2009. Atividade em contínua expansão e aprimoramento que, além de não representar um ônus para os cofres púbicos, é um verdadeiro instrumento de políticas públicas, visto que possui grande capilaridade e consegue atuar onde o Estado nem sempre se faz presente.

A atividade notarial e registral, detentora do "poder da informação", na medida em que recebe maior número de "atribuições públicas", concomitantemente cede cada vez mais suas informações ao poder público, que crescentemente disponibiliza estas para vários órgãos da administração pública, no intuito de promover a expansão das políticas públicas no Brasil (Schwarzer, 2018, P.20).

A garantia da publicidade, autenticidade, segurança e eficácia dos atos jurídicos (BRASIL, 1994) não são as únicas atribuições destes profissionais do direito, que são verdadeiros promotores da cidadania e agentes da pacificação social. Pela própria natureza dos atos praticados, os tabeliães e registradores possuem grande proximidade com a população e suas demandas, possuindo, portanto, grande relevância na localidade em que atuam.

$\mathrm{O}$ trabalho destes profissionais se destina a prevenir litígios e consequentemente promover a desjudicialização. O tabelião, como definido por Loureiro (2018, p. 48), é o “jurista do cotidiano da pessoa comum”, a quem cabe, por intermédio de sua fé pública, dar forma jurídica à vontade das partes. É o profissional de confiança dos interessados, de livre escolha, que presta aconselhamento jurídico imparcial e presencia a realização dos negócios jurídicos mais relevantes da vida do cidadão.

A assessoria jurídica prestada pelo Tabelião, no exercício de sua atividade, é um dos elementos fundamentais de sua função social, visto que não raro, especialmente no interior do Estado da Bahia, o assessoramento do Tabelião é o único acessível e disponível a qualquer cidadão que o procure, independentemente da localidade em que ele se encontre e de sua condição econômica e social.

Há no Estado da Bahia, de acordo com o Portal Justiça Aberta do Conselho Nacional de Justiça, 501 serventias extrajudiciais com atribuição de Tabelionato de Notas, sendo o quarto estado da federal com o maior quantitativo de serventias extrajudiciais desta especialidade (CNJ, 2021). A busca da sociedade pela segurança jurídica ocasionou o surgimento espontâneo do notariado na Idade Média (Loureiro, 2017), atividade que se encontra na atualidade presente em mais de 120 países ao redor do mundo, abrangendo 2/3 da população mundial (Uiln, 2021).

Enquanto as instituições mais veneráveis e poderosas ruíram com o passar dos séculos, o Notariado atravessou incólume a Queda do Império Romano, as trevas da alta Idade Média, o Renascimento, a Revolução Industrial e até mesmo a sangrenta revolta do povo contra a aristocracia. A Revolução Francesa demoliu antigas instituições, mas o notariado foi preservado e revigorado (Loureiro, 2018, p.9). 
A atividade notarial se aprimorou ao longo dos séculos e, aliada à tecnologia, assume posição de grande destaque com a publicação do Provimento $n^{\circ} 100$ do Conselho Nacional de Justiça, que regulamentou a elaboração dos atos notariais eletrônicos. Com plataforma online do Colégio Notarial do Brasil - Conselho Federal, chamada e-notariado, a população têm à sua disposição a realização dos mais diversos atos notariais em meio eletrônico, com a mesma segurança jurídica. A possibilidade de realizar escrituras e procurações públicas de forma totalmente remota, e sem custos adicionais pelo uso da plataforma, representa uma significativa ampliação do acesso simplificado aos documentos relacionados à cidadania.

O protesto de títulos, atribuição do Tabelião de Protesto, é regulamentado pela Lei federal ${ }^{\circ} 9.492$, de 10 de setembro de 1997. Definido como "ato formal e solene pelo qual se prova a inadimplência e o descumprimento de obrigação originada em títulos e outros documentos de dívida" (BRASIL, 1997), o protesto tem sua história entrelaçada aos títulos de crédito, surgido mediante uma necessidade social. Ao tratar do binômio finalístico do protesto notarial, Amadei (2020, p. 26) apresenta as finalidades do protesto

Fim-primeiro do protesto: a segurança jurídica estática, em ordem a comprovação, com fé pública, das situações cambiárias insatisfeitas; (ii) fim-secundário do protesto: a segurança jurídica dinâmica, em ordem à proteção do crédito, pela possibilidade de satisfação, com rapidez, dos títulos inadimplidos, e pela publicidade dos protestos tirados, em favor dos adquirentes de boa-fé, para a tutela dos negócios jurídicos futuros.

O instituto do protesto de títulos se aprimorou e se tornou um instrumento de desjudicialização e de cidadania, na medida em que coloca à disposição da sociedade um meio legítimo e célere para cobrança de créditos, desempenhando uma relevante função econômica. Fisher E Santos (2020) imprimem ao protesto notarial um relevante papel no desenvolvimento econômico nacional, visto que a existência de um meio célere para obter o cumprimento de uma obrigação gera segurança jurídica, o que consequentemente impacta no crédito e na geração de riquezas.

Seja como meio de estimular o devedor ao cumprimento voluntário da obrigação, seja como meio de solução extrajudicial de conflitos, o protesto se tornou verdadeiro artifício nas mãos do credor para viabilizar o rápido recebimento de seu crédito. $\mathrm{O}$ protesto se tornou, em última análise, um instrumento de proteção do crédito e da confiança naquilo que se pactuou, já que garante o cumprimento das obrigações assumidas (Fischer e Santos, 2020, P. 138).

Com a edição do Provimento $n^{\circ} 86$ do Conselho Nacional de Justiça em 29/08/2019, qualquer pessoa, física ou jurídica, pode apresentar um título a protesto sem antecipar o pagamento de emolumentos e demais despesas, desde que o vencimento tenha ocorrido há menos de um ano. Tal permissivo representa a possibilidade de qualquer pessoa ter acesso a um meio de cobrança de dívida com segurança jurídica, garantindo a "acessibilidade isonômica aos usuários" (CNJ, 2019).

Tem-se ainda em 2019, com a publicação do Provimento no 87 do Conselho Nacional de Justiça, a criação da Central Nacional de Serviços Eletrônicos dos Tabeliães de Protesto de Títulos - CENPROT, que se constitui em uma plataforma de prestação de serviços eletrônicos. Dentre os serviços prestados, há a consulta gratuita acerca da existência ou não de protesto perante qualquer Tabelionato de Protesto do Brasil, na qual o cidadão consegue obter ainda informações complementares, tais como quantidade de títulos protestados, em qual cartório se encontram estes títulos e os respectivos valores.

Os Cartórios de Registro de Imóveis são incumbidos dos registros e averbações referentes aos direitos reais sobre bens imóveis, conforme previsão do artigo 172 da Lei nº 6.015, de 31 de dezembro de 1973. Como bem ressalta Ceneviva (2008, p. 351), tais serventias na verdade possuem uma missão maior que é "levar a propriedade imobiliária a seus livros e lhe acompanhar as subsequentes mutações, inclusive constituição de ônus”. A publicidade imobiliária proporcionada pelo registro tem por finalidade proteger um direito fundamental: a propriedade. 
Estreitamente relacionado à cidadania está o direito social à moradia, que somente pode ser plenamente atendido se aliado ao direito de propriedade. Neste diapasão tem-se a publicação da Lei n ${ }^{\circ} 13.465$, de 11 de julho de 2017, que dispõe sobre a regularização fundiária rural e urbana. O intuito principal desta lei foi representar uma efetiva solução para situações irregulares consolidadas, promovendo, portanto, uma regularização dos núcleos urbanos informais em todos os seus aspectos, com vistas a garantir melhorias nas condições habitacionais, ultrapassando as questões meramente jurídicas (Macedo, 2017).

Os Cartórios de Registro Civil das Pessoas Jurídicas também são importantes instrumentos de acesso à cidadania, visto que possuem a atribuição de registrar a constituição das pessoas jurídicas de direito privado de natureza não empresária, dentre as quais se destacam as associações, sindicatos e organizações religiosas. Ressalte-se que tais atos estão diretamente relacionados a valores principiológicos preservados pela Constituição Federal, tais como a liberdade de associação, a liberdade sindical e a liberdade religiosa.

A liberdade de associação é direito fundamental garantido no artigo 5, inciso XVII da Constituição Federal, cujos atos constitutivos são de competência dos Cartórios de Registro Civil das Pessoas Jurídicas de sua sede. Somente mediante o registro obtém-se a personalidade jurídica das que se constituem em união de pessoas para fins não econômicos (BRASIL, 2002).

Sobre os Cartórios de Registro Civil das pessoas Naturais e os Ofícios da Cidadania, é correto afirmar que os Oficiais de Registro Civil das Pessoas Naturais são os titulares a quem a lei nº 8.935, de 18 de novembro de 1994, confere a atribuição de registrar, em seus livros, os atos e fatos mais elementares da vida das pessoas naturais, tais como o nascimento, casamento e óbito. De acordo com Lima Junior (2021, p. 1251), é o Cartório de Registro Civil que permite o primeiro contato do indivíduo com o Estado

A primeira relação entre pessoa e Estado em que se faz presente o exercício da dignidade da pessoa humana em busca de ser-lhe reconhecida e cidadania, ocorre nas serventias extrajudiciais de Registro Civil das Pessoas Naturais na qual, a pessoa já dotada de personalidade e sujeito de direitos e deveres, passa a existir como indivíduo singular para o Estado através de seu registro de nascimento.

Com a publicação da lei no 13.484 , de 26 de setembro de 2017, os Cartórios de Registro Civil das Pessoas Naturais foram alçados à categoria de Ofícios da Cidadania, com a finalidade de realizar convênios com órgãos públicos para a prestação de outros serviços remunerados (BRASIL, 2017). Os Oficiais de Registro Civil, com a criação do Ofício da Cidadania, tornam-se agentes ainda mais significativos na realização de políticas públicas, tendo em vista sua capilaridade única e contato direto com os cidadãos.

De acordo com o provimento $\mathrm{n}^{\circ} 66$ do Conselho Nacional de Justiça, os convênios, credenciamentos e matrículas, junto a órgãos públicos e demais entidades, a serem firmados pelos Ofícios de Registro Civil, devem ser homologados pela Corregedoria Nacional de Justiça (CNJ, 2018). Tal homologação deve ser requerida pela Associação dos Registradores das Pessoas Naturais do Brasil (ARPEN -BR) ou pela Associação dos Notários e Registradores do Brasil (ANOREG-BR).

A prestação de novos serviços pelos cartórios extrajudiciais demonstra a sua capacidade, tanto em termos estruturais quanto em aptidão técnica, para atuar nas mais diversas políticas públicas relacionadas à cidadania, especialmente naquelas em que o Estado não consegue alcançar resultado satisfatório. Ao tratar da importância dos Ofícios da Cidadania para a desjudicialização e desburocratização, Simões (2021, p. 639) trata do Ativismo Extrajudicial e explana que a atuação estatal deve se limitar a serviços públicos básicos, deixando a cargo dos cartórios extrajudiciais atos de jurisdição voluntária e demais atos inerentes à concretização dos direitos fundamentais dos cidadãos.

Diante da possibilidade de prestação de novos serviços remunerados, a população terá a sua disposição uma gama de documentos públicos e serviços prestados no mesmo local, em qualquer município do país, tais como o documento de 
identidade, título de eleitor e passaporte. Com a reunião de diversos documentos públicos nos Cartórios de Registro Civil, a população terá efetivamente um amplo acesso à cidadania plena.

No Estado da Bahia, os Ofícios da Cidadania se tornaram agentes emissores de certificados digitais, situação que facilitou o acesso à certificação digital por parte dos indivíduos que não residem em grandes centros. Ressalte-se que o certificado digital é fundamental para a integração tecnológica dos profissionais das mais diversas áreas. Os serviços de alteração e correção cadastral no CPF também já é realizado nas serventias extrajudiciais de Registro Civil do Estado da Bahia.

Em relação à emissão do documento de identidade, objeto deste estudo, foi realizada pesquisa junto às Associações dos Registradores Civis de vinte e um estados (77\%) da Federação (Rio Grande do Sul, Santa Catarina, Paraná, São Paulo, Minas Gerais, Espírito Santo, Bahia, Sergipe, Alagoas, Pernambuco, Rio Grande do Norte, Ceará, Piauí, Maranhão, Tocantins, Goiás, Mato Grosso do Sul, Mato Grosso, Amazonas, Rondônia e Acre), a fim de constar a existência de convênios com os respectivos órgãos de segurança estaduais.

Das vinte e uma Associações pesquisadas, dezessete (80\%) informaram que não há termo de convênio no estado, para a emissão das carteiras de identidade pelos cartórios de registro civil (Rio Grande do Sul, Santa Catarina, Paraná, São Paulo, Minas Gerais, Bahia, Alagoas, Pernambuco, Rio Grande do Norte, Piauí, Goiás, Mato Grosso do Sul, Mato Grosso, Rondônia, Acre, Sergipe e Tocantins).

A Associação dos Registradores Civis das Pessoas Naturais do Estado do Amazonas - ARPEN/AM realizou tentativas de implementação do convênio, mas não obteve êxito. No mesmo sentido, a ARPEN/MS ainda não obteve êxito na formalização do convênio em virtude da falta de interesse do Estado, que possui projeto para emissão das carteiras de identidade com as prefeituras municipais.

Somente as Associações dos Estados do Ceará, Maranhão e Espírito Santo, dentre as vinte e uma entidades associativas pesquisadas, informaram que o convênio para emissão das carteiras de identidade foi devidamente formalizado no estado e que este se encontra em fase de testes.

Verificou-se, portanto, que os Ofícios da Cidadania, além de possuírem notável competência técnica, contam com aparato legal para a realização de convênios com órgãos públicos e entidades interessadas (BRASIL, 1973). Entretanto, os convênios para a emissão das carteiras de identidade, cuja responsabilidade é dos estados, ainda não representam uma realidade concreta no país, devendo a investigação de tais fatores ser destinada a pesquisa futura. A emissão das carteiras de identidade em qualquer um dos 7.434 cartórios de registro civil do Brasil (CNJ, 2021) representará certamente o ápice do acesso à cidadania.

\section{Considerações Finais}

Após o caminho percorrido, a partir da questão de pesquisa de realizar uma análise sobre o trabalho de Prado (2017), no sentido de aprofundar ou atualizar o trabalho inicial por ele desenvolvido, verificando se, além das plataformas públicas e da plataforma postal, a plataforma de serviços extrajudiciais pode ser também um instrumento que o Estado brasileiro dispõe, para ampliar a oferta de serviços de acesso a cidadania, com foco mais específico para o documento certificador "Carteira de identidade (CI)" e do o objetivo proposto de analisar a plataforma pública de serviços extrajudiciais, visando compreender quais os elementos (estruturais, legais e de recursos) que possui para facilitar o acesso à cidadania, com o serviço de Carteira de identidade (CI), no estado da Bahia, entende-se que o objetivo foi plenamente alcançado.

Dentro do contexto analisado e do caminho percorrido, encontrou-se evidências de que o e-governo (E-Gov) e sua promessa de plataforma para o atendimento da cidadania, ainda está no estágio de desenvolvimento, bastante limitado a construção de marcos legais regulatórios e de desenho de uma estrutura que permita essa inclusão. Assim, enquanto esse programa vai sendo desenvolvido a passos lentos, tornam-se ainda mais necessárias as medidas de urgência para o acesso dos 
indivíduos, aos serviços de emissão de documentos certificadores da cidadania.

Em um segundo ponto, observa-se que as plataformas públicas, de bases do próprio estado da Bahia, pouco evoluíram para atender a cidadania, contando com os parcos recursos ou com os convênios frágeis com as prefeituras, conforme as constatações feitas por Prado (2017). Assim, quatro anos mais tarde, os serviços de acesso a cidadania continuam sob bases frágeis e com as mesmas lacunas apresentadas pelo autor, principalmente no tocante ao serviço de carteira de identidade. Nesse mesmo sentido, a plataforma postal, amplamente presente nos munícipios do Brasil e do estado da Bahia, pouco ou quase nada tem sido utilizada, para fazer chegar aos indivíduos serviços de acesso à cidadania.

Por outro lado, verifica-se que a partir do ano de 2017, com a nova estruturação dos serviços extrajudiciais e da consolidação de sua plataforma de serviços, com uma rede de serventias de atendimento especializados, traz um elemento novo à discussão feita por Prado (2017). Acesso aos serviços de Registro Civil de Nascimento, por exemplo, que o trabalho deste autor apontava no ano de 2017, está praticamente consolidado, com a nova plataforma. Serviços como acesso ao Cadastro de Pessoa Física - CPF, que possuía acessos em plataformas parceiras da Secretaria da Receita Federal (banco Brasil, Caixa Econômica Federal e a Plataforma de serviços Postais), conta a gora com uma rede muito ampla na prestação dos serviços, ao se incluir a plataforma de serviços extrajudiciais. Nesse sentido, esses serviços venceram as barreiras de acesso, encurtando as distâncias e ampliando a rede de prestação.

Quanto aos serviços de acesso a emissão da Carteira de Identidade - CI, verificou-se que, não apenas no Estado da Bahia, mas na grande maioria dos outros Estados (dezessete estados, no universo de vinte e um, pesquisados), não ocorreu ainda a formalização de convênio entre a entidade de classe dos registradores civis e o órgão de segurança estadual competente.

Diante da capilaridade dos Cartórios de Registro Civil no país tem-se que a formalização de convênios deve ser incansavelmente buscada pelas associações, de forma que possam fortalecer a prestação de serviços essenciais aos cidadãos em um único local, com celeridade e segurança jurídica. Constatou-se que a plataforma dos serviços extrajudiciais deve ser ainda mais explorada pelo Poder Público, em atendimento aos direitos mais elementares do cidadão. As fragilidades do convênio com prefeituras, encontrada em alguns estados da federação, foi explorada por Prado (2017), também no estado da Bahia, encontrando muitas fragilidades, desencontros e descontinuidade dos serviços.

Portanto, ficam evidentes as lacunas deixadas pelos estados da federação brasileira e, em especial ao estado da Bahia, objeto do estudo de Prado (2027), demonstrando desinteresse ou desconhecimento das plataformas que podem ser utilizadas pelos habitantes, para terem ofertas de serviços de acesso a cidadania. Assim, continua-se mantendo um processo de seletividade, com privilégios aos municípios mais bem estruturados economicamente ou com indicadores sociais, mais bem posicionados em ranking com o IDHM. Nesse sentido, em mantidas essas condições ou seu ritmo de renovação, essas lacunas de acesso a cidadania estarão presentes por muito tempo, dificultando o desfrute de uma cidadania mais plena. Continuará a ser um país seletivo, desigual e injusto, com relação a cidadania.

Este trabalho não se limita apenas a essa análise, o seu potencial de estudo e aprofundamento sobre os mais diversos programas, políticas e serviços para a cidadania, devem ser contínuos. Na medida em que avança a digitalização, muitos novos processos podem ser incluídos e facilitados, e muitos documentos podem ser transferidos dos meios físicos para meios digitais. Portanto, novos estudos podem ser realizados a partir destas constatações. Porém, uma necessidade é iminente: conceber acesso e desfrute aos habitantes do estado da Bahia à cidadania, continuará a ser um direito de todos e um dever do Estado. 


\section{Referências}

Assembleia Legislativa. Lei Estadual $n^{o}$ 3.731, de 22 de novembro 1979. Palácio do Governo do Estado da Bahia, em 22 de novembro de 1979. http://www.legislabahia.ba.gov.br/documentos/lei-no-3731-de-22-de-novembro-de-1979.

Assembleia Legislativa. Lei Estadual $n^{o}$ 12.352, de 08 de setembro 2011. Palácio do Governo do Estado da Bahia, em 08 de setembro de 2011. http://www.legislabahia.ba.gov.br/documentos/lei-no-12352-de-08-de-setembro-de-2011.

Caltram, G. A. F. (2010). O registro de nascimento como direito fundamental ao pleno exercício da cidadania. 2010. Dissertação (Mestrado) - Universidade Metodista de Piracicaba - UNIMEP, Piracicaba - SP.

Ceneviva, W. (2008). Lei dos registros públicos comentada. (18a ed.): Saraiva.

Chrispino, R. (2012). Relatório da Comissão para Erradicação do Sub-Registro de Nascimento. Rio de Janeiro: Corregedoria Geral do Rio de Janeiro.

CNJ - Conselho Nacional de Justiça. (2019). Provimento $n^{o} 86$ de 29 de agosto de 2019. https://atos.cnj.jus.br/atos/detalhar/2991.

CNJ - Conselho Nacional de Justiça. (2020). Provimento no 100 de 26 de março de 2020. https://atos.cnj.jus.br/atos/detalhar/3334.

Cortina, A. (2005). Cidadãos do Mundo: para uma teoria da cidadania: Edições Loyola.

Di Pietro, M. S. Z. (2014). Direito Administrativo. (27a ed.): Atlas.

Estrela, C. *2018). Metodologia Científica: Ciência, Ensino, Pesquisa. Editora Artes Médicas.

Giddens, A., Beck, U., \& Lash, S. (1997). Modernização Reflexiva. São Paulo: UNESP.

Giddens, A. (2008). Estado-nação e Violência. São Paulo: EDUSP.

Holston, J. (2013). Cidadania Insurgente: disfunções da democracia e da modernidade no Brasil: Companhia das Letras.

Instituto Brasileiro De Geografia e Estatística - IBGE. (2010). Estatística de Registro Civil. Rio de Janeiro.

Instituto Brasileiro De Geografia e Estatística - IBGE. (2010). Censo 2010. <http://censo2010.ibge.gov.br.

Instituto Brasileiro De Geografia e Estatística - IBGE. (2013). Concurso Público Para Outorga De Delegações De Serventias Extrajudiciais De Notas E De Registro do Estado da Bahia. http://www.cespe.unb.br/concursos/TJ_BA_13_NOTARIOS/arquivos/ED_1_2013_TJBA_NOTARIOS_13_ABT.PDF.

Lei no 8.935, de 18 de novembro de 1994. Diário Oficial da União, Brasília,18 nov. de 1994. http://www.planalto.gov.br/ccivil_03/leis/18935.htm.

Lei no 9.492, de 10 de setembro de 1997. Diário Oficial da União, Brasília,10 set. de 1997.

Lei n ${ }^{\circ} 13.484$, de 26 de setembro de 2017. Diário Oficial da União, Brasília, 26 set. de 2017.

Lima Junior, L. M. T. (2021). A evolução do sistema de registro civil das pessoas naturais para a concreção da cidadania: breve relatos acerca das novéis atribuições delegadas e expectativas acerca dos ofícios da cidadania. In: O Registro Civil na atualidade: a importância dos ofícios da cidadania na construção da sociedade atual. Salvador: Juspodivm.

Macedo, P. C. R. (2020). Regularização Fundiária Urbana e seus Mecanismos de Titulação de Ocupantes: Lei nº 13.465/2017 e Decreto nº 9.310/2018. São Paulo: Thomson Reuters Brasil.

Marshall, T. H. (1907). Cidadania classe social e status. Rio de Janeiro: Zahar.

Osborn, D., \& Sund, K. J. (2010). The future is in the post: perspctives on strategy in the postal industry. Faringon: Libri Publishing.

Pádua, E. M. M. (2016). Metodologia da Pesquisa: Abordagem teórico-prática. São Paulo: Papirus Editora.

Pereira, A. S., et al. (2018). Metodologia da pesquisa científica. [free e-book] Santa Maria/RS. Ed. UAB/NTE UFSM.

Programa das Nações Unidas Para o Desenvolvimento - PNUD. (2013). Atlas de Desenvolvimento Humano - ADHB. Brasília - DF: Instituto de Pesquisa Econômica e Aplicada - IPEA.

Prado, V. (2017). Os Correios como agente catalisador de políticas públicas para a cidadania: uma perspectiva de análise a partir da realidade do Estado da Bahia. Tese de Doutorado. Programa de Pós-Graduação em Desenvolvimento Regional e Urbano (PPDRU) da UNIFACS - Universidade Salvador. SalvadorBA.

Prado, V., Santos, J. A. G., \& Serpa, D. (2020). Políticas Sociais e Desigualdades: Herança Histórica e Desafios Atuais. Revista Fatec de Tecnologia e Ciências. Alagoinhas - BA.

Schwarzer, M. (2017). Informação é poder. O Registro Civil das Pessoas Naturais - reflexões sobre temas atuais. Salvador: Juspodivm.

Simões, J. P. P. (2021). Ativismo Extrajudicial: a ideia depois de formada é mais fácil de ser aperfeiçoada. In: O Registro Civil na atualidade: a importância dos ofícios da cidadania na construção da sociedade atual. Salvador: Juspodivm.

Souza, J. (2000). A modernização seletiva: Editora UNB. 
Research, Society and Development, v. 10, n. 11, e266101119677, 2021

(CC BY 4.0) | ISSN 2525-3409 | DOI: http://dx.doi.org/10.33448/rsd-v10i11.19677

Souza, J. (2006) A construção social da subcidadania: IUPERJ.

Souza, J. (2011). A ralé brasileira: quem é e como vive: UFMG.

Souza, J. (2012). Os batalhadores brasileiros: nova classe média ou nova classe trabalhadora? Belo Horizonte: UFMG.

Spínola, N. D. (2009). A trilha perdida: caminhos e descaminhos do desenvolvimento baiano no século XX. Salvador: UNIFACS.

Yin, R. K. (2015). O Estudo de Caso: Bookman. 